\title{
FAKTOR PENDORONG DAN PENARIK WISATAWAN BACKPACKER MANCANEGARA BERWISATA KE BALI
}

\author{
Gayatri Manik \\ I Ketut Suwena \\ I Wayan Suardana \\ Email : yayatri15@yahoo.com \\ PS. S1 Industri Perjalanan Wisata \\ Fakultas Pariwisata UNUD
}

\begin{abstract}
Trend backpackers is growing in various areas, including in Bali. Backpackers have been identified as having "a preference for budget accommodation, independently organized travel and emphasis on meeting other travellers, longer rather than brief holidays. The purpose of this research are to anlyses the push and pull factors that motivate the foreign backpacker tourists traveled to Bali. Sample on this research is 200 respondents of backpackers and using purposive sampling technique. Offline questionnaires are used for data collecting and the analysis technique is based on factor analysis. The results of research shows that the push factors backpackers traveled to Bali are (1) facilitation of social interaction, (2) self-identity, (3) relaxation, (4) prestige, (5) adventure (6) novelty. The push factor that dominantly is facilitation of social interaction. The pull factors are (1) cultural/historical, (2) affordable price, (3) variety seeking, (4) tourism facilities, (5) safety and clean, (6) environment. The pull factor that dominantly is Cultural / Historical.
\end{abstract}

Keywords: Factor Analysis, Push \& Pull Factor, Backpacker Tourist.

\section{PENDAHULUAN}

Pariwisata semakin berkembang seiring dengan pergerakan manusia itu sendiri dalam mencari sesuatu yang baru dan ingin memenuhi kebutuhan akan pengalaman wisata dan interaksi sosial yang tidak ditemui di tempat asalnya. Sejak lama kegiatan berwisata sudah menjadi permintaan yang wajar bagi negara maju karena aktivitas berwisata sudah menjadi kebutuhan dan gaya hidup yang bisa bersaing dengan barang mewah lainnya. Wisatawan yang akan berkunjung ke suatu tempat ditentukan oleh motivasi dan keinginan individu itu sendiri (faktor pendorong) serta adanya daya tarik (faktor penarik) yang ditawarkan di suatu objek wisata. Banyak faktor yang memotivasi seseorang untuk melakukan perjalanan wisata, seperti: keluar dari rutinitas sehari-hari, menyegarkan pikiran, mencari sesuatu yang baru, memanjakan diri, bersenang-senang dan sebagainya. Seiring berjalannya waktu, kegiatan berwisata bukanlah sesuatu yang bersifat mahal lagi melainkan sudah bisa dijangkau oleh setiap orang. Banyak cara yang dapat dilakukan untuk berwisata, salah satu caranya adalah dengan "backpacking" atau sering disebut sebuah trend berwisata murah dan praktis. Backpacking adalah sebuah istilah yang digunakan untuk mencerminkan sebuah bentuk dari perjalanan berwisata dengan biaya rendah.

Pelaksanaan wisata backpacking dianggap lebih mudah dan praktis karena didukung dengan banyaknya maskapai penerbangan bertarif rendah (Low Cost Carrier), penginapan dan paket akomodasi dengan biaya yang murah diberbagai belahan dunia, serta kemajuan teknologi dalam berbagai bentuk komunikasi. Menurunnya biaya transportasi dan 
pertumbuhan media komunikasi melalui internet membuat perjalanan wisata backpacking ini terus meningkat (Maritha, 2010:1).

Wisatawan yang melakukan backpacking disebut sebagai backpacker. Maoz (dalam Faddillah, 2009:5) menyebutkan para backpacker sebagai wisatawan yang secara mandiri mengorganisasikan perjalanan panjang dengan banyak tujuan tempat wisata, rencana perjalanan yang juga fleksibel, berusaha untuk mengalami cara hidup lokal dan fokus kegiatan wisata mereka pada wisata alam, kebudayaan, dan petualangan. Hal yang paling membedakan wisatawan backpacker dengan wisatawan pada umumnya adalah backpacker melakukan perjalanan secara independent, segala urusan perjalanan diurus sendiri seperti pemilihan akomodasi, transportasi, destinasi yang akan dikunjungi hingga itinerary dan tidak melibatkan travel agent seperti wisatawan pada umumnya. Cohen (dalam Rodriguez, 2011:8) menyatakan bahwa tourist bersifat sukarela, sementara, bepergian dengan mengharapkan kesenangan dari hal-hal yang baru dan perubahan pengalaman yang relatif lama dan tidak berulang. Wisatawan mencari alternatif untuk mendapatkan apa yang dicita-citakan dan melakukan hal yang berbeda dari pariwisata massal. Backpacker merupakan salah satu dari sub-kelompok yang terlepas dari pariwisata massal dan berusaha untuk mencapai pengalaman pariwisata yang lebih lengkap Currie (dalam Menuh, 2015).

Virgies Travel Guide yang ditayangkan di Metro TV menghadirkan lima kampung backpaker terbaik di Indonesia dalam segmen top five list pada episode 24, Minggu 29 November 2008. Top five list tersebut adalah Popies Lane (Kuta, Bali) sebagai peringkat pertama. Bali terkenal sebagai tujuan utama para backpacker, karena tersedianya berbagai fasilitas - fasilitas yang memadai seperti penginapan murah dan lokasinya yang sangat strategis. Saat ini trend wisata backpacker semakin berkembang di berbagai daerah khususnya di Bali, meskipun tidak adanya data statistik pasti yang membedakan antara wisatawan backpacker dengan wisatawan konvensional lainnya.

Melihat trend wisatawan backpacker yang semakin populer dan masih jarangnya yang meneliti mengenai wisatawan backpacker maka ingin diketahui lebih lanjut mengenai keberadaan wisatawan backpacker meliputi karakteristik serta menganalisis faktor pendorong dan faktor penarik yang memotivasi wisatawan backpacker berwisata ke Bali.

\section{METODE PENELITIAN}

Lokasi dilaksanakan di beberapa objek wisata yang terkenal dengan wisatawan dan penginapan backpacker di Bali seperti Kuta, Sanur dan Ubud. Berdasarkan teori push pull factor, penulis mengaitkan komponenkomponen faktor pendorong dan penarik tersebut dengan motivasi wisatawan backpacker dalam melakukan perjalanan wisata ke Bali.

Jenis data yang digunakan adalah data kuantitatif dan kualitatif. Sumber data menggunakan data primer dan data sekunder. Pengumpulan data dilakukan dengan cara observasi, wawancara, kuesioner dan kepustakaan. Teknik penentuan sampel adalah purposive sampling dengan jumlah sampel sebanyak 200 dengan mengacu pada Roscoe (dalam Sugiyono, 2014) yang menjelaskan bahwa ukuran sampel yang layak dalam penelitian adalah antara 30 sampai dengan 500 adalah tepat untuk kebanyakan penelitian. Teknik analisis data yang digunakan dalam penelitian ini adalah analisis faktor dengan menggunakan bantuan SPSS Versi 16.0 for windows.

\section{HASIL DAN PEMBAHASAN Karakteristik Wisatawan Backpacker Mancanegara Berwisata ke Bali}

Karakteristik wisatawan backpacker yang berwisata ke Bali didominasi oleh wisatawan yang berasal dari Benua Australia dan didominasi oleh kaum perempuan dengan usia 20-30 tahun. Wisatawan backpacker memiliki pendidikan tinggi dengan pekerjaan beragam. Karakteristik perjalanan wisatawan backpacker adalah melakukan perjalanan sendiri, menggunakan internet sebagai sumber informasi berwisata, menggunakan sepeda motor sebagai transportasi. Wisatawan backpacker memilih menginap di hostel dan makan di restoran lokal. Rata-rata tinggalnya $>14$ hari dengan alokasi budget \pm Rp. 5.000.000, menyukai aktivitas diving. Wisatawan backpacker yang berkunjung ke Bali sangat menyukai keanekaragaman 
budaya dan tradisi yang ada di Ubud. Akivitas favorit backpacker selama mengunjungi Ubud adalah melihat tradisi dan kebudayaan Bali dan senang berinteraksi dengan masyarakat lokal.

\section{Uji validitas dan reliabilitas}

Uji validitas dan reliabilitas digunakan untuk mengetahui apakah seluruh item pertanyaan dalam kuisioner valid. Butir pertanyaan dikatakan valid jika nilai $\mathrm{r}_{\text {hitung }}$ lebih besar dari nilai $r_{\text {tabel }}$ dan dikatakan reliabel jika alpha cronbanch > 0,6 (Sujarweni, 2015). Seluruh indikator dalam kuisioner memiliki nilai $r_{\text {hitung }}$ lebih besar dari nilai $r_{\text {tabel }}(0,306)$ dimana berdasarkan Product Moment Pearson, item kuisioner adalah valid. Pada uji realibilitas yang telah dilakukan dengan rumus alpha cronbanch, diketahui bahwa seluruh indikator variabel memiliki nilai koefisien alpha yang lebih besar dari 0,6, dimana indikator indikator dalam kuisioner dinyatakan reliable.

\section{Analisis Faktor Pendorong}

Analisis faktor dilakukan menggunakan 20 indikator faktor pendorong (selanjutnya disebut variabel). Berikut ini akan dijelaskan hasil analisis faktor tersebut:

\section{KMO and Bartlett's Test}

Kaiser Meyer Olkin Measure of Sampling Adequacy (KMO MSA) digunakan untuk melihat apakah variabel-variabel tersebut layak atau tidak untuk dianalisis lebih lanjut. Untuk dapat dilakukan analisis faktor, nilai KMO dianggap cukup apabila nilai KMO $\geq$ 0,5 (Suliyanto, 2005). Hasil Uji KaiserMeyer-Olkin (KMO) yang diperoleh adalah 0,757. Angka ini sudah melebihi 0,5, sehingga dapat disimpulkan bahwa bahwa variabelvariabel yang digunakan dalam penelitian ini bisa dianalisis lebih lanjut.

\section{Total Variance Explained}

Total Variance Explained bertujuan untuk menunjukkan hasil perhitungan analisis faktor dan digunakan untuk mengetahui banyaknya faktor yang terbentuk. Faktor yang terbentuk harus memiliki nilai eigen values $\geq 1$ (Suliyanto, 2005). Hasil analisis faktor menunjukkan banyaknya faktor yang terbentuk dari 20 variabel, terdapat 6 (enam) faktor yang memiliki eigenvalue lebih dari satu. Keenam faktor tersebut merupakan faktorfaktor yang mendorong wisatawan backpacker melakukan perjalanan ke Bali.

\section{Rotated Component Matrix}

Rotated Component Matrix menunjukkan distribusi variabel-variabel yang telah diekstrak ke dalam faktor yang telah terbentuk berdasarkan factor loading setelah dilakukan proses rotasi. Variabel yang memiliki factor loading $\leq 0.5$ dianggap memiliki kontribusi yang lemah terhadap faktor yang terbentuk sehingga harus dieliminasi atau dibuang dari faktor yang terbentuk sebelumnya (Suliyanto, 2005). 20 variabel yang telah dianalisis melalui Rotated Component Matrix terdapat 2 variabel yang tidak memenuhi nilai $\geq 0,5$ sehingga harus dikeluarkan dari model dan menyisakan 18 variabel. Kemudian pembentukan faktor-faktor baru ini akan dinamai yang cocok dengan variabel-variabel yang sudah terkumpul dalam masing-masing faktor.

\section{Interpretasi Faktor}

Interpretasi faktor dilakukan dengan cara mengelompokkan variabel yang mempunyai factor loading yang tinggi ke dalam masingmasing faktor yang terbentuk dan harus diberi nama relevan atau label mengacu pada variabel-variabel yang membentuk faktor bersangkutan. Hasil interpretasi faktor pendorong menghasilkan nilai kumulatif varian dari seluruh faktor yang terbentuk mencapai $66,758 \%$. Keenam faktor yang terbentuk adalah faktor Facilitation of social interaction dengan varian $24,959 \%$, faktor Self-identity dengan varian $11,834 \%$, faktor Relaxation dengan varian 9,396\%, faktor Prestige dengan varian $8,071 \%$, faktor Adventure dengan varian $7,362 \%$, dan faktor Novelty dengan varian $5,136 \%$.

\section{Analisis Faktor Penarik}

Analisis faktor dilakukan menggunakan 20 indikator faktor penarik (selanjutnya disebut variabel). Berikut ini akan dijelaskan hasil analisis faktor tersebut. 


\section{KMO and Bartlett's Test}

Kaiser Meyer Olkin Measure of Sampling Adequacy (KMO MSA) digunakan untuk melihat apakah variabel-variabel tersebut layak atau tidak dianalisis lebih lanjut. Untuk dapat dilakukan analisis faktor, nilai KMO dianggap cukup apabila nilai KMO $\geq 0,5$ (Suliyanto, 2005). Hasil Uji KaiserMeyer-Olkin (KMO) yang diperoleh adalah 0,743 . Angka ini sudah melebihi 0,5 , sehingga variabel-variabel yang digunakan dalam penelitian ini bisa dianalisis lebih lanjut.

\section{Total Variance Explained}

Total Variance Explained bertujuan menunjukkan hasil perhitungan analisis faktor dan digunakan untuk mengetahui banyaknya faktor terbentuk. Hasil analisis faktor menunjukkan banyaknya faktor yang terbentuk dari 20 variabel adalah 6 (enam) faktor yang memiliki eigenvalue lebih dari satu. Keenam faktor tersebut merupakan faktor-faktor yang menarik wisatawan backpacker melakukan perjalanan ke Bali.

\section{Rotated Component Matrix}

Rotated Component Matrix menunjukkan distribusi variabel-variabel yang telah diekstrak ke dalam faktor yang terbentuk berdasarkan factor loading setelah dilakukan proses rotasi. Dua puluh (20) variabel yang dianalisis melalui Rotated Component Matrix terdapat 1 variabel yang tidak memenuhi nilai $\geq 0,5$ sehingga harus dikeluarkan dari model dan menyisakan 19 variabel yang diteliti lebih lanjut.

\section{Interpretasi Faktor}

Interpretasi faktor dilakukan dengan cara mengelompokkan variabel yang mempunyai factor loading yang tinggi ke dalam masingmasing faktor yang terbentuk dan harus diberi nama relevan atau label mengacu pada variabel-variabel yang membentuk faktor bersangkutan. Hasil interpretasi faktor penarik menghasilkan nilai kumulatif varian dari seluruh faktor yang terbentuk mencapai $66.294 \%$. Keenam faktor yang terbentuk adalah faktor Cultural/Historical dengan varian $22.990 \%$, faktor Affordable price dengan varian $12.931 \%$, faktor Variety seeking dengan varian 9,576\%, faktor Tourism facilities dengan varian
$7.939 \%$, faktor Safety and Clean dengan varian $7.196 \%$ dan Environment dengan varian $5,661 \%$.

Faktor Pendorong Wisatawan Backpacker Mancanegara Berwisata ke Bali

Berdasarkan hasil analisis faktor maka faktor pendorong wisatawan backpacker berwisata ke Bali sebagai berikut.

1. Faktor Pertama yaitu facilitation of social interaction memiliki eigen value paling besar yaitu 4,992 dan terdiri atas variabel (1) bertemu dengan orang-orang baru, (2) berinteraksi dengan masyarakat lokal, (3) melihat cara hidup dan budaya yang berbeda.

2. Faktor kedua yaitu self-fulfilment memiliki eigen value sebesar 2,367 terdiri atas variabel (1) menemukan jati diri, (2) meningkatkan kemampuan, mengevaluasi diri sendiri.

3. Faktor ketiga yaitu relaxation memiliki eigen value sebesar 1,879 terdiri atas variabel (1) menjauhkan diri dari lingkungan sehari-hari, (2) untuk melepaskan diri sejenak dari pekerjaan, (3) menghilangkan stress dan ketegangan, (4) untuk merelaksasi keadaan fisik dan mental

4. Faktor keempat yaitu prestige memiliki eigen value sebesar 1,614 terdiri atas variabel (1) untuk meningkatkan status dan harga diri, (2) untuk merasakan pengalaman akan gaya hidup, (3) untuk meningkatkan status sosial.

5. Faktor kelima yaitu adventure memiliki eigen value sebesar 1,472 terdiri atas variabel (1) untuk berpetualang dan dekat dengan alam, (2) untuk melakukan hal-hal yang menantang, (3) untuk menjadi sehat dan bugar, (4) untuk mengeksplor tempattempat yang belum familiar.

6. Faktor keenam yaitu novelty memiliki eigen value 1,027 terdiri atas variabel (1) untuk bersenang-senang dan merasa bahagia.

Adapun faktor yang paling dominan dalam mendorong wisatawan backpacker berwisata ke Bali dapat dilihat melalui nilai eigenvalue yang paling besar dari keenam faktor yaitu faktor facilitation of social interaction dengan nilai 
eigenvalue sebesar 4,992. Berdasarkan hasil wawancara dengan beberapa wisatawan backpacker menunjukkan bahwa motivasi mereka berwisata ke Bali adalah bertitik pada keinginan atau kebutuhan wisatawan akan pengalaman ingin bertemu dan berinteraksi dengan orang-orang baru, mengenal lebih dekat dengan budaya masyarakat lokal, dan berinteraksi dengan wisatawan backpacker lainnya.

\section{Faktor Penarik Wisatawan Backpacker Mancanegara Berwisata ke Bali}

Berdasarkan hasil analisis faktor maka faktor penarik wisatawan backpacker berwisata ke Bali sebagai berikut.

1. Faktor pertama yaitu Cultural/Historical memiliki eigen value yang paling besar yaitu 4,598 terdiri atas variabel (1) terdapat keanekaragaman budaya, (2) terdapat kesenian, adat dan tradisi, (3) terdapat bangunan bersejarah, pura, museum, (4) terdapat kuliner lokal yang bervariasi, (5) terdapat festival dan events.

2. Faktor kedua yaitu Affordable price memiliki eigen value sebesar 2,586 terdiri atas variabel (1) harga barang, akomodasi dan pelayanan yang terjangkau, (2) nilai mata uang yang terjangkau, (3) kenyamanan/bebas visa, (4) harga tujuan wisata yang terjangkau.

3. Faktor ketiga yaitu Variety seeking memiliki eigen value sebesar 1,915 terdiri atas variabel (1) terdapat tempat hiburan dan entertain, (2) terdapat pusat perbelanjaan yang bervariasi, (3) atraksi wisata yang bervariasi, (4) Terdapat ketersediaan kegiatan outdoor.

4. Faktor keempat yaitu Tourism facilities memiliki eigen value sebesar 1,588 terdiri atas variabel (1) Destinasi yang popular dan sangat direkomendasikan, (2) Terdapat pilihan akomodasi yang bervariasi, (3) Akomodasi yang bersih dan nyaman.

5. Faktor kelima yaitu Safety and Clean memiliki eigen value sebesar 1,439 dengan variabel (1) destinasi wisata yang aman, dan (2) lingkungan wisata yang bersih dan sehat.

6. Faktor keenam yaitu Environment memiliki eigen value 1,132 terdiri atas variabel (1) pemandangan alam dan pantai yang indah, dan (2) Cuaca yang bersahabat.

Adapun faktor yang paling dominan dalam menarik wisatawan backpacker melakukan perjalanan ke Bali dapat dilihat melalui nilai eigenvalue yang paling besar yaitu faktor Cultural/Historical, dengan nilai eigenvalue sebesar 4,598. Berdasarkan hasil wawancara dengan beberapa wisatawan backpacker menyatakan bahwa motivasi mereka berkunjung ke Bali adalah ingin mengenal lebih dekat kebudayaan, adat dan tradisi lokal. Wisatawan backpacker tertarik mengikuti upacara-upacara yang dilakukan oleh masyarakat, seperti upacara adat dan keagamaan.

\section{SIMPULAN DAN SARAN Simpulan}

Berdasarkan karakterisik wisatawan backpacker mancanegara yang berkunjung ke Bali adalah wisatawan perempuan dengan usia muda berumur 20-30 tahun, melakukan perjalanan ke Bali untuk pertama kalinya, dan bepergian sendiri serta menggunakan internet sebagai sumber informasi. Mereka tinggal di akomodasi murah seperti hostel, guesthouse, makan/minum di restoran lokal dan memilih sepeda motor sebagai transportasi. Backpacker tinggal di Bali $>14$ hari dengan budget \pm Rp.5.000.000. Backpacker yang berkunjung ke Bali sangat menyukai wisata diving dan keanekaragaman budaya dan tradisi yang ada di Ubud.

Faktor-faktor yang mendorong wisatawan backpacker berkunjung ke Bali terdiri atas enam (6) faktor yaitu (1) facilitation of social interaction, (2) self-identity, (3) relaxation, (4) prestige, (5) adventure, dan (6) novelty. Faktor paling dominan adalah facilitation of social interaction. Faktor penarik wisatawan backpacker berkunjung ke Bali ada enam (6) faktor yaitu (1) cultural/historical, (2) affordable price, (3) variety seeking, (4) tourism facilities, (5) safety and clean, dan (6) environment. Faktor dominan adalah cultural/historical.

\section{Saran}

Perlu diselenggarakan beberapa event atau atraksi budaya yang bisa menarik minat wisatawan backpacker berkunjung ke Bali. Bagi 
peneliti selanjutnya, diharapkan bisa mengembangkan penelitian tentang minat dan potensi wisata backpacker serta dampaknya bagi perkembangan pariwisata di Indonesia.

\section{DAFTAR PUSTAKA}

Fadlilah. T. 2009. Hubungan Faktor-faktor Pendorong dan Faktor-faktor Motivasi Penarik untuk Melakukan Wisata Backpacking. Skripsi. Universitas Indonesia.

Maritha, Devi Putri. 2010. Profil Pola Pengeluaran Wisatawan Asing Ala "Backpacker" di Yogyakarta. Universitas Sebelas Maret Surakarta.

Menuh, N. 2015. Karakteristik Wisatawan Backpacker Mancanegara dan Dampaknya Terhadap Perkembangan Pariwisata di Kuta, Bali. Tesis.Program Studi Kajian Pariwisata. Program Pascasarjana. Universitas Udayana.

Rodriguez, R. 2011. Backpacking Tourism In Tampere. Degree Programme in Tourism. Tampere University of Applied Sciences.

Sujarweni, W. 2015. SPSS Untuk Penelitian. Yogyakarta: Pustaka Baru Press. Alfabeta

Sugiyono. 2014. Metode Penelitian Kuantitatif Kualitatif dan $R \& D$. Bandung : Alfabeta.

Suliyanto (2005). Analisis data dalam aplikasi pemasaran. Bogor: Ghalia Indonesia. 